\title{
Juha Ihmemaassa
}

'Joka osaa tehdä, hän tekee. Joka ei osaa tehdä, hän opettaa tekemistä. joka ei osaa opettaa tekemistä, hän tutkii tekemisen opettamista. Joka ei osaa tutkia tekemisen opettamista, hän tutkii tekemisen opettamisen tutkimisen metodologisia ja filosofisia perusteita." (Suomalaista yliopistohuumoria, Hemánus 1993).

\section{Suoranta, Juha 1995. Tekstit, murrokset ja muutos - kolme näkökulmaa laadullisen tut- kimuksen metodologiaan. Acta Universitatis Lapponiensis 10. Lapin yliopisto: Rovaniemi.} s. 245.

Tällä lainauksella voisi KL Juha Suoranta varsin hyvin aloittaa kasvatustieteen alaan kuuluvan väitöskirjansa, mutta ei "sillä sen tähden, että hän itse on kärsinyt ja ollut kiusattu, voi hän kiusattuja auttaa" (Hebr. 2:18) ole sekään ihan kehno, sillä käsillä o eva työ on varsin omaleimainen esitys modernissa suomalaisessa kasvatustieteessä. Vertailukohtaa voidaan hakea myös täysin toisaalta. Myös Camel bootsien mainoksessa mies tallailee omia polkujaan, mutta kuuluuko Suoranta töineen samaan villien ja vapaiden sukukuntaan?

Suorannan "tutkielma", joksi hän itse väitöskirjaansa kutsuu, koostuu kolmesta osasta: johdannosta, tekstiosiosta ja jälkipuheesta. Näistä keskimmäinen, tekstiosio, koostuu kahdeksasta luvusta, joista osa on julkaistu aiemmin artikkeleina tai pidetty esitelminä, ja jotka on myöhemmin kirjoitettu laajennettuina väitöskirjaa varten. Siten jotkut kirjan luvuista saattavat olla lukijakunnalle tuttuja mm. Kasvatus- ja Aikuiskasvatus-lehdistä, toisten ollessa - enemmän tai vähemmän - tuntemattomampia esityksiä. Yhtenäistä kaikille teoksen luvuille on kuitenkin se, että ne kaikki koskevat laadullisen tutkimuksen metodologiaa ja ovat tulleet julkaistuksi tai julki - jossain muodossa - aikaisemminkin. Kyseessä on siis artikkeliväitöskirja, joka tosin sisältönsä ja rakenteensa puolesta käy kyllä monografianakin.

Tutkimuksellaan Suoranta kirjoittaa haluavansa paneutua kysymykseen, millaista metodologista kysymistä, millaista metodologiaa, laadullisen tutkimuksen yhteydessä on muun muassa mahdollista harjoittaa? Väitöskirjatutkimuksen tarkoituksena on kirjoittajan mukaan rakentava keskustelu laadullisen tutkimuksen metodologiasta. Ensiksikin siksi, että hänen mukaansa ihmistieteissä vallitsee yleinen murroskausi, jolloin näyttäisi siltä, että selviltä vaikuttaneiden menetelmällisten ratkaisujen aika olisi ohi, ja toiseksi laadullisen tutkimuksen metodologinen tutkimus on uusien ja mahdollisesti luovien tutkimus- ja ajattelutapojen ekstrapolointia.

Suoranta onkin asettanut tutkielmansa yleiseksi perustavoitteeksi "tutkia laadullisiin tutkimusmenetelmiin sisältyviä rajoja ja mahdollisuuksia", ja siten tutkimustehtävässä on kyse laadullisen tutkimuksen metodologisista rajoista ja muodoista, joka tekijän mukaan vie yhden tien sijasta kolmeen suuntaan. Nämä kolme tietä/suuntaa tai temaattista kenttää laadullisen tutkimuksen metodologisiin kysymyksiin ovat aineisto,- teoria- ja muutoshakuiset näkökulmat.

Aineistohakuisen metodologian muodostavat tutkimuksen kaksi ensimmäistä lukua (1-2), joissa molemmissa on kyse rajoiltaan selkeästä suppean ja esimerkinomaisen empiirisen aineiston laadullisesta analyysistä. Tunnusomaista aineistohakuiselle metodologialle on empiirisen aineiston olemassaolo, johon testataan vaihtoehtoisia analyysitapoja. Tutkimuksen kolme seuraavaa lukua (3-5) muodostaa teoriahakuisen metodologian, keskittyen tarkastelemaan laadullisen tutkimuksen teoreettisia kysymyksiä. Tällöin tekniikan hallinta ja sen soveltaminen jäävä taka-alalle, tieteellisen toiminnan perimmäisten kysymysten ja tieteenfilosofisten kysymysten noustessa agendan kärkeen. Kolmannen temaattisen kentän, muutoshakuisen metodologian, muodostavat jälleen tutkimuksen kolme seuraavaa lukua (6-8). Näissä luvuissa on 
tarkoituksena Suorannan mukaan "tutkia joltain osin empiirisen laadullisen tutkimuksen menetelmähistoriaa ja vetää laadullisen tutkimuksen linjoja tähän päivään. "

Luulisi, että Suoranta tutkisi metodologista keskustelua - siis muiden käymänä - laajemminkin, minkä vuoksi onkin yllättävää, että tutkimuskohteena ovat hänen omat kirjoituksensa, joita tarkastelemalla hän rortylaisen edifioivan ajattelun ideasta ja tutkimuksen pragmaattisesta pohjavireestä käsin pyrkii tarkastelemaan metodologisia kysymyksiä ja viemään keskustelua uusiin - tai toisenlaisiin - suuntiin. Omaleimaisuutta tutkimuksen käsittelyssä on ennen kaikkea se, ettei Suoranta ole pyrkinyt hävittämään kirjoittavaa subjektia ja tutkimuksen kontekstia ympäröivän tiedeyhteisön skientistisestä ilmapiiristä tai kulttuurista huolimatta (mistä myös Raiski (1990) kirjoittaa väitöskirjansa johdannossa).

Perinteisesti niin kutsutussa vakavasti otettavassa tieteellisessä tutkimuksessahan subjekti esittäytyy vain kainosti ja hieman häpeillen esipuheessa kiitellessään häntä tutkimuksenteossa tukeneita tahoja. Suoranta kirjoittaakin pyrkivänsä "oman äänen käyttöön" ja ottaa uskaliaasti vertailukohteekseen mm. Descartesin Metodin esityksen vuodelta 1637, jossa ajatteleva Minä on esillä teoksen loppuun asti. Ilmeisesti juuri ajattelevan Minän esiintyminen tutkimuksen sivuilla johti osaltaan siihen, että Suorannan vastaväittäjänä toiminut professori Niinistö huomauttikin väitöstilaisuudessa (14.10.1995) tutkimuksessa olevan vahva postmodernistinen, relativistinen ja konstruktivistinen viritys. Lisäksi vastaväittäjä kaipaili tutkimukseen myös saksalaista hermeneutiikkaa, jonka kirjoittaja tosin rajaa jo lähtökohtaisesti käsittelynsä ulkopuolelle.

Suorannan metodi/tutkimusote/lähestymistapa/kirjoittamistyyli on mielenkiintoinen, sillä hän muodostaa omat metodologian luokkansa omien kirjoitustensa perusteella. Sen sijaan, että hän rakentaisi metodologiatypologiansa kenties joidenkin muiden kirjoittamien tekstien perusteella, hänen omat kirjoituksensa muodostavat materiaalin, jonka pohjalta metodologioiden typologia mahdollistuu. Sinänsä hauskaa on, että tutkimuksen taustalla väijyvä hahmoton mutta nimeämätön paha (vaka vanha positivismi) livahtaa takaovesta sisään Suorannan ajaessa sitä hiilihangolla samalla etuovesta ulos; Suoranta puristaa itsensä typologioihin (=yleistyksiin) pyrkiessään näyttämään muille tietä ulos positivismin ikeen alta. Tuottaessaan yhden kertomuksen metodien ihmemaasta, niin samalla kirjoittaja rajoittaa niitä muita mahdollisia tapoja, joilla asiat voitaisiin nähdä ja esittää.

1irjoittajan toisenlainen lähestymistapa muistuttaa 1800-luvun psykologiaan liittyviä asenteita joiden mukaan todellisen sielutieteen tutkimuskohteen ajateltiin olevan sielu. Ainoa luonteva tapa saada tietoa sielusta oli kääntää katse sisäänpäin eli introspektio. Vaikka introspektion vastaliikkeen eli behaviorismin hurjimpia väitteitä ei uskoisikaan on kai selvää, että introspektiivinen menetelmä sisältää vakavia ongelmia. On tietysti varsin subjektiivista arvioida, onnistuuko kirjoittaja tässä tapauksessa nuo vaarat välttämäänMutta saattaa olla, että amerikkalaisen pragmatismin eräät perusviritteet muodostavat Suorannan tapauksessa pelastavan oljenkorren.

Muutoinkin tutkimuksen temaattiset tieteenfilosofiset ainekset ovat varsin mielenkiintoisella tavalla eklektisiä; Suoranta sekoittaa iloisesti ja täysin siekailematta toisiinsa Michel Foucault'a, Ricbard Rortya, pragmatismia, Väinö Linnaa ja Raamattua. Vanhemman polven tieteenharjoittaja saattaa moisesta epäpyhästä narratiivisuudesta kavahtaa takajaloilleen ja nuorempikin voi sitä hieman kummeksua. Suorannan keittämä eklektinen soppa on kuitenkin nieltävissä, koska hän kirjoittaa hyvin; rehellisesti, rohkeasti ja avoimesti. Kyseessä onkin ehkä enemmänkin suorantalainen kuin mikään muu tutkielma.

Lukukokemuksena kirja on nautittava siitä huolimatta, että - kuten Suorannan vastaväittäjäkin huomautti -teokseen on livahtanut joitain yhdyssana- ja painovirheitä. Kirjaa voi huoletta suositella ihmistieteen tieteenfilosofiasta ja metodologiasta kiinnostuneille. 